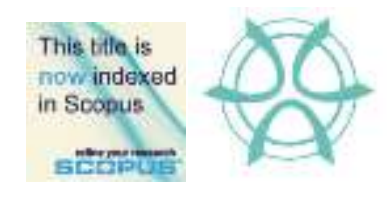

\title{
TRAVELLERS' PERCEPTION OF WORSHIP FACILITIES FOR MULTIMODAL USERS OF MRT SBK LINE
}

\author{
Nur Athifah A. Kadir', Muhammad Rijal Mohamad², Oladejo Aliu Olabayonle ${ }^{3}$, \\ Mohammad Zarif Mohd Zahari ${ }^{4}$, Syahriah Bachok ${ }^{5}$, Mariana Mohamed Osman ${ }^{6}$ \\ 1,2,3,4,56 Kulliyyah of Architecture and Environmental Design \\ INTERNATIONAL ISLAMIC UNIVERSITY MALAYSIA
}

\begin{abstract}
The complete opening of the new Mass Rapid Transit System (MRT) Sungai Buloh - Kajang (SBK) of Klang Valley, Malaysia since July 2017 has been supported positively by transit researchers and public transport advocators alike. Multimodal public transport users make trips, usually involving transferring at interchanges. These interchanges are provided with several amenities facilitating each trip leg. This research recorded the perception of users of worship facilities provided at an interchanging node where several rails, bus, taxi, and other paratransit systems meet. This new rail system intersects with the other systems at Muzium Negara station. Using intercept off-board face to face questionnaire survey method, perception of the quality of worship facilities was captured between May and August 2019. Several explanatory variables such as socioeconomic and trip characteristics were set against the perception to identify factors influencing the perception. Results of the correlational analysis showed that both socio-demographic and trip characteristics influenced perception to various statistical significance degrees. Findings suggested that worship facilities were most utilised by passengers of MRT who relatively lower income, engaged in the public, specifically educational sector. Usage of MRT for commuting within the Klang Valley on monthly basis. The improvements in ventilation systems, prayer hall size and design, floor cleanliness, lighting and mirror design as well as shoe rack/clean area design were most sought by these passengers. As such, these should be the focus of strategies to be promptly adopted by interchanging nodes building managers to increase the quality of worship places provision.
\end{abstract}

Keywords: Mass Rapid Transit, Travellers' Perception, Worship Facilities

\footnotetext{
${ }^{1}$ Master Student. Email: nurathifahkadir@yahoo.com
} 


\section{INTRODUCTION}

Mass Rapid Transit (MRT) Sungai Buloh - Kajang (SBK) system's Kajang Semantan section began commercial operation on 17th July 2017. Before this, Sungai Buloh- Semantan section has begun operating on 16 December in the previous year. It is aligned along $53 \mathrm{~km}$ route linking neighbourhoods around 31 stations in north-westerly and south-easterly directions. A four-car system, with a headway of 3.5 minutes (in peak hours) had been adopted with a capacity of 1,200 passengers. The system was estimated to carry 400,000 daily riders. Eight interchanging stations link this line to other rail systems in Klang Valley, Malaysia. One of these is Muzium Negara station where passengers may transfer to the other seven rail and various other public transport systems in the conurbation. The corresponding interchange station for Kelana Jaya Light Rail Transit system, KLIA Ekspres system, KLIA Transit system, two KTM Komuter systems, KTM Intercity system, KTM ETS system and Monorail station is KL Sentral station.

Figure 1 overleaf shows the integrated rail system in Klang Valley. The Figure also depicts how the distance between Muzium Negara and KL Sentral stations can be bridged by walking, hence the shared interchanging facilities for the multimodal users. A comprehensive system is expected with the completion of the second MRT system (SSP MRT) and the third light rail system (LRT3), facilitating many travellers in the region.

For multimodal travellers, some of the journeys made were cross-states, cross-region in nature, and sometimes internationally bound. Journeys can be long and exhausting, for example, those traversing borders of urban conurbations, regions, states and nations. Travel time of these trips can be long and a minimum of one transfer need to be performed. For these trip makers, amenities while interchanging can be very important to facilitate and accommodate the wideranging needs of passengers in transit. 
Nur Athifah A. Kadir, Muhammad Rijal Mohamad, Oladejo Aliu Olabayonle, Mohammad Zarif Mohd Zahari Syahriah Bachok, Mariana Mohamed Osman

Travellers' Perception of Worship Facilities for Multimodal Users of MRT SBK Line

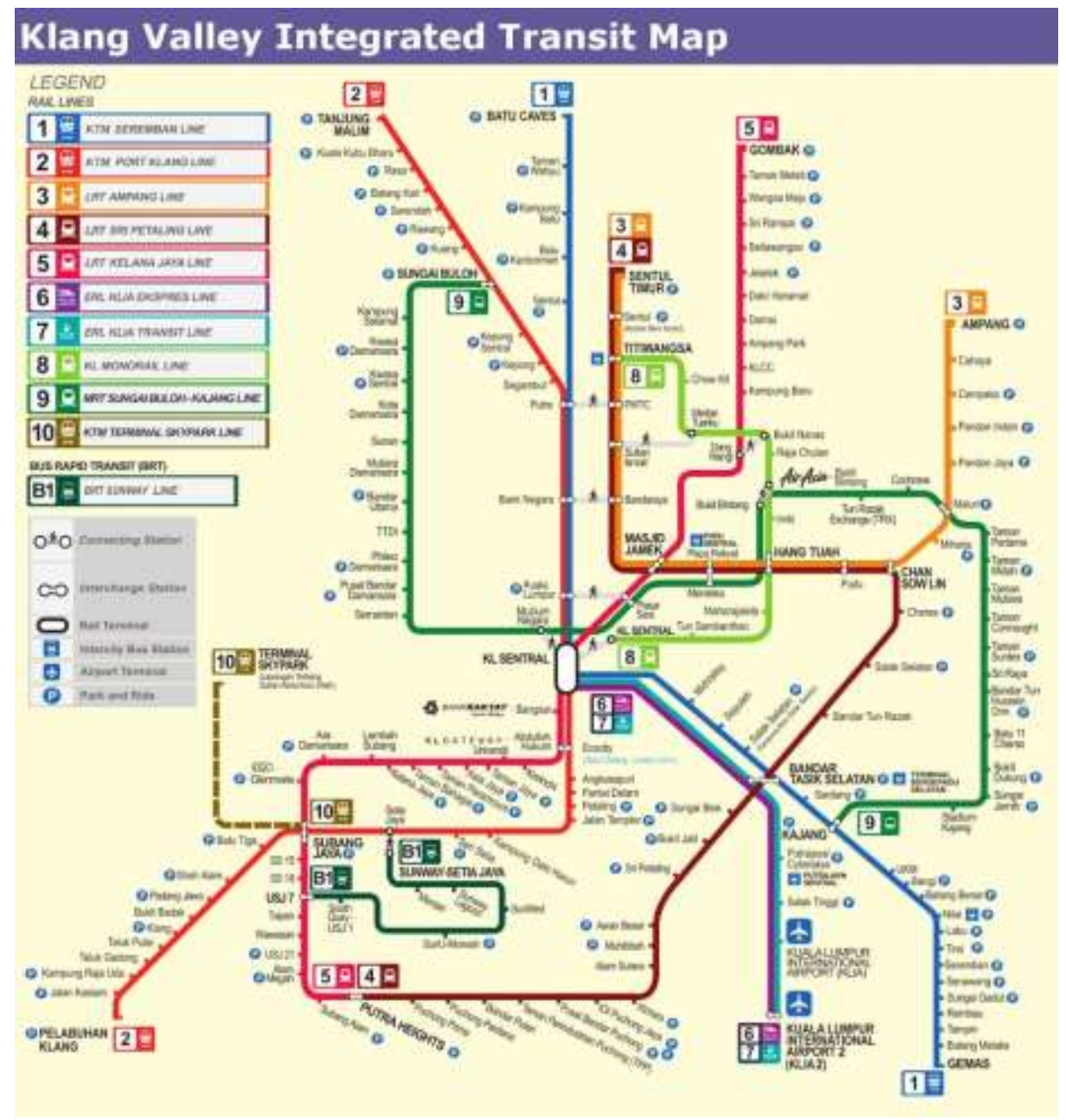

Figure 1: Klang Valley Integrated Public Transport Map Source: https://www.klia2.info/rail/mrt-sbk/(cited on 18 August 2020)

Specifically, those who are culturally or religiously inclined among these travellers would be obliged to perform spiritual activities including yoga, meditations and prayers. The performances would either be bound by physical space or time window or unique diet requirements or even distinctive physiological undertakings. As such, building managers of public transport interchanges or nodes or termini need to engage in quality assessment of their assets and facilities from time to time to ensure consistency and continuity of quality improvement. 
Among the facilities provided is the worship place. This research singles out this facility due to the limited explanation of the factors affecting the perception of users on the quality of such provision (Ref). Besides, longer trips necessitate journeys to be broken into legs. For journey made beyond certain time windows, worshipping activities may need to be performed en-route the journeys. Malaysia is a multi-cultural, multi-religion nation, with tourism as one of the largest GDP contributors. Many of these tourists originated from other nations with similar multi-cultural, multi-religion population composition. To increase the attractiveness of public transport to existing and prospective users, an assessment on this narrowed and specialised section of interchanging nodes is essential.

The Conceptualisation of Facilitation of Muslim Travellers Conceptually, journeys made using public transportation can be less attractive than those of private vehicles. Various strategies have been mooted to increase the attractiveness of public transportation and ease those travelling on these modes. Long journeys, fatigue resulting from transfers and the lack of amenities are some of the challenges faced by users of public transportation.

Malaysia is highly ranked as a tourist destination, with nearly 30 million visitors travelling into the nation on annual basis. Having tourism is one of the major GDP contributors, the Malaysian government also advocated the facilitation of tourists at various tourism locations and journeys along with these destinations. Various efforts had been made to attract Muslim tourists from all around the world which has led to an increase of Muslim tourists' arrivals in the country. Malaysia has become a top halal-friendly Muslim destination worldwide (CRaHFT, 2014). Among those travellers are those coming from the regions where the Muslim population are the majority. These travellers are obliged to perform prayers as stipulated by the teaching of their religion. These prayers follow strict rules and prescriptions. Table 1 below shows how Malaysia faired in the league of Muslim tourist destinations. a benchmark for other destinations to target Muslim tourists and/ or to market the destination as "Muslim friendly destination". The number of shariah-compliant transit area is growing in some destination. Muslim friendly transit area delivers Muslim guests with the availability of prayer facilities at tourist spots and public premises (transit area, $\mathrm{R} \& \mathrm{R}$, shopping malls, theme parks, hotels). 
Nur Athifah A. Kadir, Muhammad Rijal Mohamad, Oladejo Aliu Olabayonle, Mohammad Zarif Mohd Zahari Syahriah Bachok, Mariana Mohamed Osman

Travellers' Perception of Worship Facilities for Multimodal Users of MRT SBK Line

Table 1: The top ten Holiday Destinations in OIC Category (*OIC: Organization of Islamic Cooperation)

\begin{tabular}{|l|c|}
\hline Holiday Destination (OIC Countries) & Ranking \\
\hline Malaysia & 1 \\
\hline United Arab Emirates & 2 \\
\hline Turkey & 4 \\
\hline Indonesia & 5 \\
\hline Saudi Arabia & 6 \\
\hline Morocco & 7 \\
\hline Jordon & 8 \\
\hline Qatar & 9 \\
\hline Tunisia & 10 \\
\hline Egypt Source: Crescentrating's Halal Friendly Travel (CRaHFT) Ranking 2014
\end{tabular}

Salman and Hasim (2012) found that only a very small number of Muslim tourists have an image of Malaysia as an Islamic country and an element of evaluation included satisfaction with worship facilities. A provision must make the user comfortable and convenient to perform prayer.

Conceptually too, several components of worship or prayer facilities have been propagated by the respective researcher of religious studies. For Muslims specifically, four of these components played major roles in quality setting of worship facilities. They are design, cleanliness, distance and capacity as well as latent aspects such as comfort, convenience, safety, security and timeliness. In Malaysia, most buildings were obliged to subscribe to the Guideline for Planning Mosque and Prayer facilities (Plan Malaysia, 2000). The general and specific guidelines covered rules and regulations on the placement of the mosque and the layout for space utilization. Similarly, four important criteria for transit area's prayer facilities were categorised as design, number and location, cleanliness and convenient (PlanMalaysia, 2000). The requirement of performing prayer five times a day is taking into consideration by providing Muslim tourists with prayer facilities and the Islamic call to prayer which are necessary for the development of Islamic oriented tourism standards and as the identified Islamic attributes of destination that may attract Muslim tourists. 
PLANNING MALAYSIA

Journal of the Malaysia Institute of Planners (2020

\section{RESEARCH BACKGROUND Worship and Worship facility}

Subscribing to the second pillar of Islamic beliefs (Islam-world.net, 2011), performance five times' act of prayer or 'Solat' which include before dawn (Subuh), noon (Zuhur), afternoon (Asar), after sunset (Maghrib), and evening (Isyak) respectively is obligatory. In Malaysia, the warrant for provision of places or facilities to perform these prayers is ruled for public buildings or buildings utilised for public use (Planning Guidelines for Worship and Prayer facilities, 2000). Mohsin and Mohammed (2011) found that users were highly attracted by the availability of mosques and this facility was rated as the most attractive pull travel motivations for the destination's attributes. Weidenfeld (2006) suggests that proximity to a mosque may influence Muslim tourists' preferences when making hotel reservations. Mohsin (2005) concluded that the selection of the Northern Territory of Australia as a holidaying tourism destination for Muslims was influenced by the availability of mosques. Syed (2001) also suggested that the availability of mosques at tourist destinations may increase satisfaction levels. The mosque itself may be considered a tourist attraction if it is unique and outstanding (Henderson, 2003). Mohsin and Ryan (1997) further recommend that ease of access to Islamic services are important upon exploring Malaysian and Indonesian business people's attitude towards the possibility of holidaying in Australia. It is also suggested that Middle Eastern countries take concrete steps to develop Islamic tourism internally by having prayer rooms at tourism sites (WTM, 2007).

The teaching of Islam advocates cleansing of oneself before going for prayers (including cleaning their private parts water from urine and stools, after answering the call of nature) (Quran At-Taubah: 108). To support the overflowing of worshippers during congregational prayers especially Friday prayers, most Masjid has provided sufficient large areas for ablution and toilets. It is understandable for architects to design Masjid' ablution area and toilets to be situated at ground level or one level under the prayer hall, and this is because to cater large usage capacity, space zoning and ease of cleaning purposes for the prayer hall (Guideline for Planning Mosque and Surau PlanMalaysia, 2000). According to the guideline, there are three fundamentals in preparing places of worship for Muslims namely placement of mosque and the layout for space utilization. The guideline on selecting a suitable site for prayer facilities at transit area focused on four important criteria which included the design, number and location, cleanliness and convenience. By law, building owners providing prayer room for building approval must fulfil requirements of placing an ablution area, adequate lighting, fans or air-conditioning, facilities for the disabled and segregation area for both men and women (NST, July 2013). 
Nur Athifah A. Kadir, Muhammad Rijal Mohamad, Oladejo Aliu Olabayonle, Mohammad Zarif Mohd Zahari Syahriah Bachok, Mariana Mohamed Osman

Travellers' Perception of Worship Facilities for Multimodal Users of MRT SBK Line

\section{The Conceptualisation of Satisfaction and Perception}

Perception of utility or disutility of a product or a service can be expressed as satisfaction level. Satisfaction is defined as the customers' post-purchase comparison between pre-purchase expectation and performance or experience received (Oliver, 1980; Zeithaml et al., 1990, Oliver 1999). The psychological state of pleasure or displeasure, feeling of well-being or disappointment when comparing and contrasting would also feed into such perception and satisfaction (Pizam and Ellis, 1999; Kotler, 2000; Kim et. al, 2003).

The satisfaction level is an essential yardstick for the assessment of quality services. For service industries including the tourism sector, satisfaction level reflects customers' experience and expectation which will lead to loyalty, repeat use, willingness to recommend and would influence other future behaviour (Young, 2000; Barsky and Nash, 2003; Chang and Chen, 1998; Oliver, 1999; Pullman and Gross, 2003). For businesses and firms including building and transit area managers, satisfaction levels are important due to the capability of image creation and revenue increment (Baker, 1987; Bitner, 1986; Boom and Bitner, 1982; Kotler, 1973; Shostack, 1977; Upah and Fulton, 1985; Zeithaml, Parasuraman and Berry, 1985). Hence, three important aspects to be emphasised when describing perception are customer satisfaction, expectation and experience.

Factors influencing satisfaction and perception have been researched by many. Gender has been proven to influence the perceived image (Chen \& Kerstetter, 1999). Other socio-demographic factors such as age and marital status had a role in determining users' behaviour (Hwang, Kim and Hyun, 2013). Baloglu and McCleary (2000) supported the notion that age influenced the perceived image of a particular destination.

Hwang, Kim and Hyun (2013) proved the existence and extent of geographical origin and travel attributes' influence on satisfaction and perception. Views towards trip attributes can be heterogeneous among travellers. Likewise, tourists of different cultures (Mayo \& Jarvis, 1981; Mill \& Morrison, 1985) or different countries (Mill \& Morrison, 1985; Calantone, Di Benedeto, Hakam, \& Bojanic, 1989; and Chen \& Kerstetter, 1999) may perceive the destinations differently.

Perception and satisfaction influenced the user's behaviour. Perception and satisfaction also played a role when a user assesses the quality of a destination (Heung \& Quf, 2000; Etchner and Ritchie (1993). Research (Goodrich, 1977; Holloway, 1986; Shih, 1986; Van Raaij, 1986) emphasised that due to the imperfect information about a destination, users depended on media or social groups (Mok and Armstrong, 1996) to compensate for this lack to evaluate attributes related to the destination (Baker \& Crompton, 2000; Kozak, 2002; Yoon \& Uysal, 2005; Alegre \& Garau, 2010). 
Therefore, this paper attempts at explaining how prayer facilities assist in making the break(s) along a single journey comfortable and ease the passengers' search for obliged conducts of yoga or meditation or prayer in between their journeys. Furthermore, this paper also aims at explaining parameters influencing passengers' perception of the prayer facilities' quality that may enhance their overall experiences travelling as multimodal public transport users.

\section{METHODOLOGY}

Intercept off-board questionnaire survey method has been employed from May 2019 until August 2019. Prospective respondents were approached based on convenient sampling due to logistic issues and minimal disturbance to passengers' comfort level being conditioned by the building management's approval. Screening involves determining that the samples consisted of MRT users who made multimodal trips with travel time extending beyond the shortest prayer time of one hour (i.e. Subuh and Maghrib prayers have the narrowest time window). Some 200 users were approached but only 80 performed their prayers in the facilities provided at the interchanging station.

The questionnaire was divided into three sections. The first section captured socio-demographic characteristics, followed by travel and trip attributes. The final section dealt with the perception of prayer facilities provided. The assessment of satisfaction level was divided into four intervals (very satisfactory, satisfactory, dissatisfactory and very dissatisfactory).

The Design elements evaluated were the size of the prayer hall, floor marking for the congregation, ablution area, shoe rack/clean area, lighting and mirror. Space for praying, floor, ablution area, shoe rack, ventilation are elements to be assessed for their Cleanliness. Distance from toilet or ticketing counter/platform, between male and female areas, between ablution and praying areas, directional signage, congregational standing space were items related to qualities of Distance and Capacity. Other Latent components, for instance, safety, comfort, timeliness, sense of direction, manoeuvrability can be referred to as the levels of safety of belongings, timely announcement and display for the prayer time window, qiblah direction, fixtures and fittings as well as convenience for a person with disabilities (PWD) and universal design.

\section{FINDINGS AND DISCUSSION}

Female and male users surveyed were equally distributed (50\% respectively). The majority (62.5\%) of MRT passengers intercepted had an average monthly household income of below RM2000. Some $26.3 \%$ reported bringing home between RM2000 and RM3999. About 8.8\% earned RM4000 to RM5999 on 
Nur Athifah A. Kadir, Muhammad Rijal Mohamad, Oladejo Aliu Olabayonle, Mohammad Zarif Mohd Zahari Syahriah Bachok, Mariana Mohamed Osman

Travellers' Perception of Worship Facilities for Multimodal Users of MRT SBK Line

average monthly as a household. The remaining 2.5\% fall under the RM6000 and above income category.

More than $62 \%$ were employed in the public sector while $26.3 \%$ were in the private sector. About $8.8 \%$ were self-employed. The majority $(52.5 \%)$ of users surveyed were either employed in the educational sector or students. Some $12.5 \%$ respectively were employed at executive or professional levels and in the sale or retail sector. About $8.8 \%$ were administrative or managerial employees and some $1.3 \%$ were housewives.

About one third (33.8\%) users surveyed reached or departed from the station by rail, followed by a bus (31.3\%). A quarter (25\%) of the respondents used e-hailing and taxis as egress and access mode from and to the station. The remaining multimodal users reported the use of flight $(6.3 \%)$ and pedal power $(3.8 \%)$ to reach and leave the station.

The majority $(73.8 \%)$ of users intercepted were short distance travellers. About $18.8 \%$ made local trips traversing the Klang Valley while some $6.3 \%$ were international travellers. The remainder were regional travellers from or to outer Klang Valley.

Correspondingly, $35 \%$ made commuting trips to and from workplaces, with some $18.8 \%$ attending their appointments or meetings and $2.5 \%$ made trips either to or from educational institutions. Some $43.8 \%$ were making trips for leisure, shopping or touristic purposes.

Some $35 \%$ of respondents were first time users of MRT SBK line. About one third (33.8\%) made the trip on MRT on monthly basis, while one eighth $(12.5 \%)$ made MRT trip on weekly basis. Some $11.3 \%$ used the MRT once in a year. Daily MRT commuters formed some $7.5 \%$ from the total passengers surveyed.

Users intercepted expressed their overall satisfaction with the four variables tested. The table 2 below depicts the distribution of satisfaction levels.

Table 2: The distribution of satisfaction levels

Users' overall perception of design, cleanliness, distance and latent qualities $(\mathbf{n}=\mathbf{8 0})$

\begin{tabular}{|l|c|c|c|c|}
\hline $\begin{array}{c}\text { Assessment } \\
\text { level }\end{array}$ & Overall design & $\begin{array}{c}\text { Overall } \\
\text { cleanliness }\end{array}$ & $\begin{array}{c}\text { Overall } \\
\text { distance }\end{array}$ & $\begin{array}{c}\text { Overall latent } \\
\text { aspects }\end{array}$ \\
\hline Yes agreable & 92.5 & 88.7 & 71.3 & 82.5 \\
\hline Not agreeable & 7.5 & 11.3 & 28.7 & 17.5 \\
\hline Total & 100.0 & 100.0 & 100.0 & 100.0 \\
\hline
\end{tabular}

From the above Table 2, it can be seen that high levels of overall satisfaction for each quality of prayer facility, with an overall agreement of $71.3 \%$ 
and above. The highest agreement was with overall design (92.5\%), followed by cleanliness $(88.7 \%)$ and latent aspects $(82.5 \%)$.

Meanwhile, the following set of Tables provide further details about the satisfaction level towards each item of the four main qualities of prayer facilities under assessment.

Table 3: Users' perception of prayer facilities quality (Design and Cleanliness) $n=80$

\begin{tabular}{|c|c|c|c|c|c|c|c|c|c|c|}
\hline & \multicolumn{5}{|c|}{ Design } & \multicolumn{5}{|c|}{ Cleanliness } \\
\hline 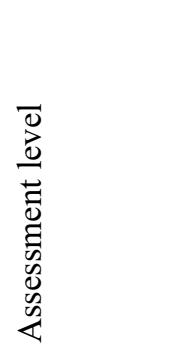 & 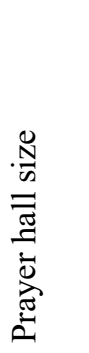 & 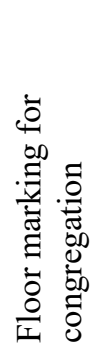 & 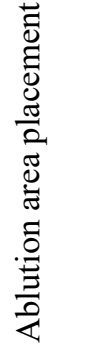 & 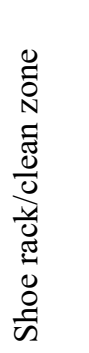 & 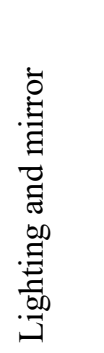 & 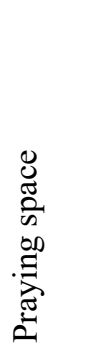 & $\frac{\grave{0}}{\frac{\partial}{I}}$ & 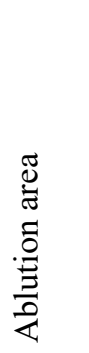 & 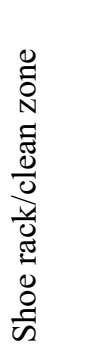 & 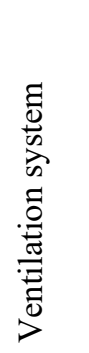 \\
\hline $\begin{array}{l}\text { Very } \\
\text { dissatisfied }\end{array}$ & 3.8 & 0.0 & 0.0 & 1.3 & 1.3 & 0.0 & 0.0 & 0.0 & 1.3 & 1.3 \\
\hline Dissatisfied & 13.8 & 5. & 5.0 & 8.8 & 10.0 & 17.5 & 17.5 & 6.3 & 12.5 & 18.8 \\
\hline Satisfied & 66.2 & 85.0 & 85.0 & 78.7 & 77.4 & 66.2 & 68.7 & 83.7 & 76.2 & 72.2 \\
\hline $\begin{array}{l}\text { Very } \\
\text { satisfied }\end{array}$ & 16.2 & 10.0 & 10.0 & 11.2 & 11.3 & 16.3 & 13.8 & 10.0 & 10.0 & 7.5 \\
\hline Total & 100.0 & 100.0 & 100.0 & 100.0 & 100.0 & 100.0 & 100.0 & 100.0 & 100.0 & 100.0 \\
\hline
\end{tabular}

From the above Table 3, an overall positive pattern of perception towards prayer facilities was captured for Design and Cleanliness components. High dissatisfactory $(0 \%)$ was not found for items such as floor marking for congregational prayer (design), placement of ablution area (design), praying space (cleanliness), floor (cleanliness) and ablution area (cleanliness). Dissatisfaction was highest for ventilation system (cleanliness, 20.1\%), prayer hall size (design, $17.6 \%$ ), praying space (cleanliness, 17.5\%), floor (cleanliness, $17.5 \%$ ), shoe rack/clean zone (cleanliness, $13.8 \%$ ), lighting and mirror (design, $11.3 \%$ ) and shoe rack/clean zone (design, $10.1 \%$ ).

High levels of satisfaction for items prayer hall size (design, 16.2\%) and prayer space (cleanliness, $16.3 \%$ ) were captured. Other items with high levels of satisfaction included floor (cleanliness, 13.8\%), lighting and mirror (design, $11.3 \%)$ and shoe rack/clean zone design (11.2\%).

The Table 4 below shows an overall satisfactory perception of Distance and Latent components. From this Table, it can be assumed that high satisfaction levels for almost all items, with none ( $0 \%$ respectively) high dissatisfaction 
Nur Athifah A. Kadir, Muhammad Rijal Mohamad, Oladejo Aliu Olabayonle, Mohammad Zarif Mohd Zahari Syahriah Bachok, Mariana Mohamed Osman

Travellers' Perception of Worship Facilities for Multimodal Users of MRT SBK Line

recorded for the distance between ablution and prayer areas (distance) and qiblah direction (latent).

Dissatisfaction was captured by items by such as perceived distance as indicated by directional signage (43.8\%), the distance between other interchanges facilities and the prayer hall (41.3\%), standing distance available when praying in the congregation $(30.1 \%)$, timely display and announcement of the start prayer time (30.1\%), PWD and universal design comfort and convenience (27.6\%) and distance between male and female sections within the prayer hall $(21.3 \%)$.

Table 4: Users' perception of prayer facilities quality (Distance and Latent) $n=80$

\begin{tabular}{|c|c|c|c|c|c|c|c|c|c|c|}
\hline & \multicolumn{5}{|c|}{ Distance } & \multicolumn{5}{|c|}{ Latent } \\
\hline 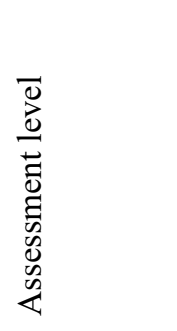 & 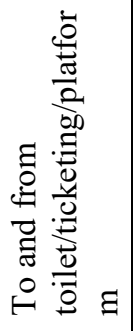 & 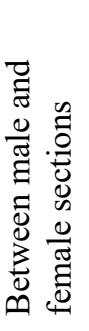 & 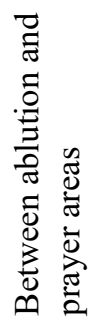 & 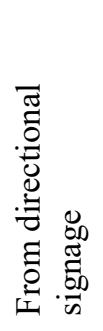 & 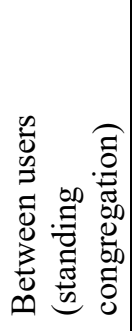 & 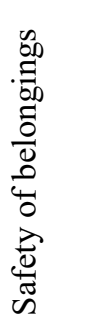 & 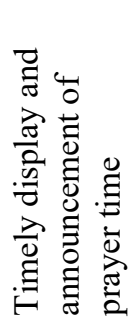 & 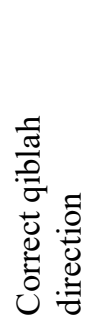 & 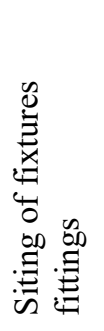 & 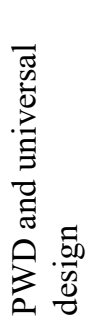 \\
\hline $\begin{array}{l}\text { Very } \\
\text { dissatisfied }\end{array}$ & 7.5 & 5.0 & 0.0 & 3.8 & 6.3 & 1.3 & 16.3 & 0.0 & 7.5 & 21.3 \\
\hline Dissatisfied & 33.8 & 16.3 & 1.3 & 40.0 & 23.8 & 6.3 & 13.8 & 0.0 & 11.3 & 6.3 \\
\hline Satisfied & 53.7 & 66.2 & 71.2 & 53.7 & 67.4 & 76.2 & 58.7 & 80.0 & 67.4 & 65.0 \\
\hline $\begin{array}{l}\text { Very } \\
\text { satisfied }\end{array}$ & 5.0 & 12.5 & 27.5 & 2.5 & 2.5 & 16.2 & 11.2 & 20.0 & 13.8 & 7.4 \\
\hline Total & 100.0 & 100.0 & 100.0 & 100.0 & 100.0 & 100.0 & 100.0 & 100.0 & 100.0 & 100.0 \\
\hline
\end{tabular}

Inferential Analysis

The Table 5 below highlights the results of correlational tests carried out on the parameters.

Table 5: Spearman correlation results

\begin{tabular}{|c|l|c|c|}
\hline $\begin{array}{c}\text { Independent } \\
\text { variable }\end{array}$ & \multicolumn{1}{|c|}{ Dependent variable } & $\begin{array}{c}\text { p-value } \\
\text { (significance) }\end{array}$ & $\begin{array}{c}\text { Spearman-rho } \\
\text { coefficient }\end{array}$ \\
\hline \multirow{2}{*}{ Gender } & Prayer hall size (design) & $0.000^{* *}$ & 0.456 \\
\cline { 2 - 4 } & Ventilation (cleanliness) & $0.057+$ & -0.214 \\
\cline { 2 - 4 } & $\begin{array}{l}\text { Prayer hall to transit } \\
\text { facilities (distance) }\end{array}$ & $0.000^{* *}$ & -0.624 \\
\cline { 2 - 4 } & $\begin{array}{l}\text { Male and female sections } \\
\text { (distance) }\end{array}$ & $0.007^{* *}$ & -0.301 \\
\hline
\end{tabular}


PLANNING MALAYSIA

Journal of the Malaysia Institute of Planners (2020

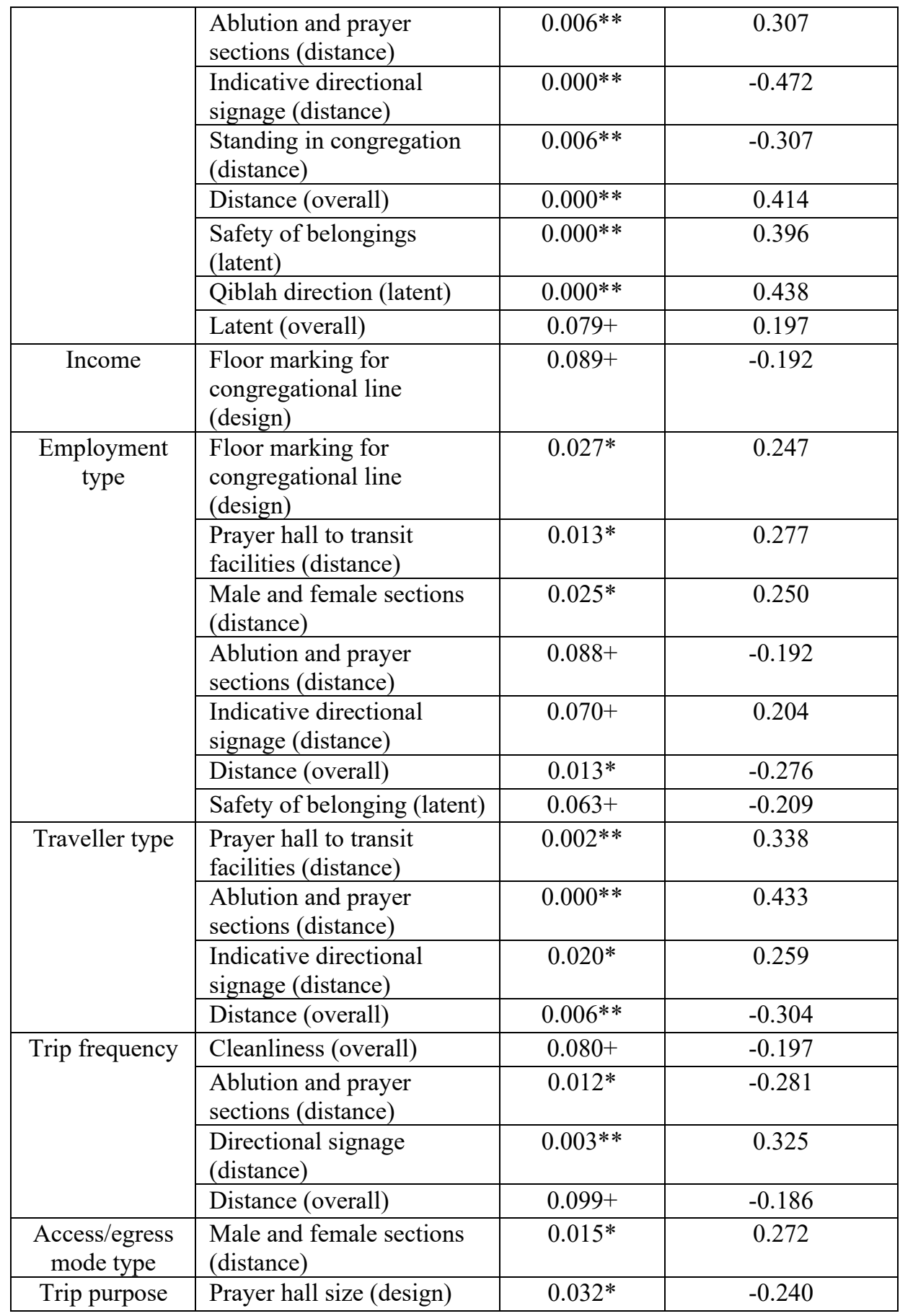


Nur Athifah A. Kadir, Muhammad Rijal Mohamad, Oladejo Aliu Olabayonle, Mohammad Zarif Mohd Zahari Syahriah Bachok, Mariana Mohamed Osman

Travellers' Perception of Worship Facilities for Multimodal Users of MRT SBK Line

\begin{tabular}{|l|l|c|c|}
\hline & $\begin{array}{l}\text { Shoe rack/clean zone } \\
\text { (design) }\end{array}$ & $0.087+$ & -0.192 \\
\cline { 2 - 4 } & $\begin{array}{l}\text { Lighting and mirror } \\
\text { (design) }\end{array}$ & $0.056+$ & -0.214 \\
\cline { 2 - 4 } & Qiblah direction (latent) & $0.054+$ & -0.217 \\
\hline
\end{tabular}

**. Correlation is significant at the 0.01 level (2-tailed).

*. Correlation is significant at the 0.05 level (2-tailed).

+ . Correlation is significant at the 0.1 level (2-tailed).

From the above Table 5, it can be seen that gender has an impact on 11 out of the 24 items tested. It was anticipated being female perception can differ especially with regards to privacy, security, walking distance and cleanliness. This has been depicted by correlational significance (at various degrees of confidence) of prayer hall size, ventilation, distances to bridge from the facilities of the interchanges to the prayer hall, distances between facilities within the prayer hall, the safety of personal belongings, qiblah direction and the overall comfort and convenience.

Floor marking for congregational prayer was significantly influenced by income. Meanwhile, it can be established that perception regarding distances to bridge from the facilities of the interchanges to the prayer hall, distance between facilities within the prayer hall and safety of personal belongings was related to the employment type.

Trip characteristics such as traveller type, trip frequency, access and egress mode as well as a trip purpose were influential on various prayer facilities quality. The assessment showed a significant correlation (to a varying degree) between traveller types and perception towards distances between interchanges facilities and prayer hall as well as between facilities provided within the hall.

Frequency of travelling by MRT has an influence over perception regarding cleanliness as well as three items of distances to be covered on foot when journeys were broken for praying intention. The separation between male and female sections within the prayer hall was differently perceived by users accessing and egressing the station using different modes.

The trip purpose has an impact on items such as prayer hall size, designs of shoe rack/clean zone and lighting and mirrors placement as well as qiblah direction.

\section{Site Observation and Analysis}

A thorough site observation and study have been conducted during non-peak hour with minimal users of the musolla located at both Kuala Lumpur Sentral transit hub and Kuala Lumpur International Airport, Sepang. This is mainly because to seek the best preparation or quality of the facility that the users will get.

The observation was recorded through the pictures taken: 

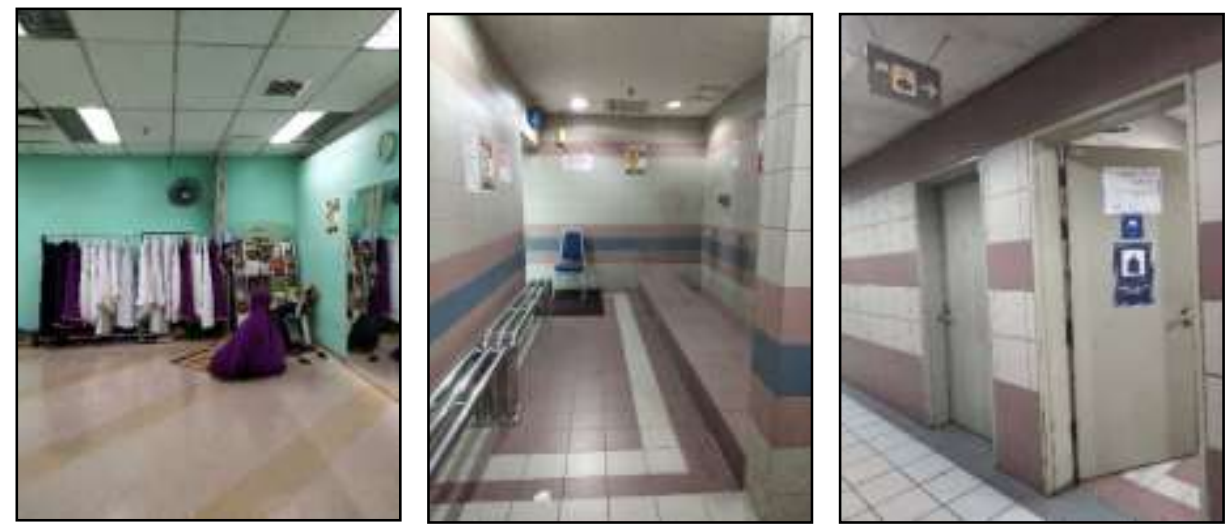

Figure 2: The worship facility, musolla of KL Sentral before peak hour.
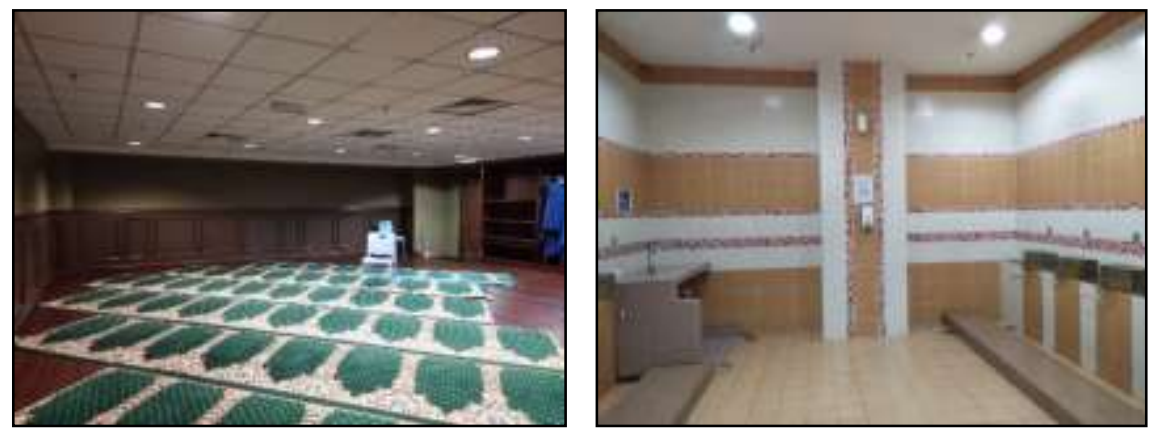

Figure 3: The clean ablution area and neat worship hall of KLIA, Sepang.

Figure 2 and Figure 3 both demonstrated that the place was regularly cleaned by staff in duty to maintain the hygiene and quality of the praying hall. Each facility is accommodated with good signage, directions and universal design.

\section{RECOMMENDATION AND CONCLUSION}

This paper is instrumental in extracting the factors influencing perception towards interchanges facilities, in particular the worship amenities for multimodal travellers using the MRT SBK system of Klang Valley. From the survey, the majority of passengers intercepted using the facility come from a relatively lower income group, working in the public sector or studying in various educational institutions, accessing and egressing Muzium Negara station using other rails, buses and taxis or e-hailing services. These multimodal users were short distance and local (Klang Valley) travellers whose travel time transgressed beyond a single prayer time window and for commuting purpose. 
Nur Athifah A. Kadir, Muhammad Rijal Mohamad, Oladejo Aliu Olabayonle, Mohammad Zarif Mohd Zahari Syahriah Bachok, Mariana Mohamed Osman

Travellers' Perception of Worship Facilities for Multimodal Users of MRT SBK Line

Generally, passengers intercepted were satisfied with the four components namely Design, Cleanliness, Distance and Latent qualities of prayer facilities. Gender, income and employment types were socio-demographic characteristics influencing the users' perception. Traveller types, trip frequency, access egress mode and trip purpose also important roles in perceiving the qualities of worship amenities provided by the public transport interchange building managers.

There are two ways to improve user satisfaction using the prayer facilities at transit area. The first is service improvement to enhance the user experience and the second is to efficiently provide support amenities such as cleanliness and comfortable prayer cloth, ablution area, prayer area and shoe area. However, the first approach is widely used in management and achieved great success. In the future, transit area needs adjustment like continuous improvement namely number, location and design of prayer facilities as well as manageable walking distances between facilities especially for the already physically fatigue users who had to transfer between various modes to reach their final destinations. Other latent items such as comfort, safety and convenience may add value to the quality of the facilities, thus decreasing the disutility associated with multimodal travel.

In conclusion, this paper has explained the relationships between the satisfaction of the facility provided at public transport interchange of a newly operational MRT system in Klang Valley and various socio-demographic characteristics and trip attributes. The issues of quality must be addressed by focusing on the items significantly correlated to the perception as having been discussed in this research.

\section{ACKNOWLEDGEMENT}

The authors would like to extend their appreciations to IIIUM and Ministry of Higher Education. This research was supported in part by Fundamental Research Grant Scheme, Ministry of Higher Education, Malaysia (FRGS/1/2019/TK08/UIAM/02/1)

\section{REFERENCES}

Battour et al., 2010, 2011; Battour \& Ismail, 2016; Hamid et al., 2016; Misiani Mwencha \& Makau Muathe, 2018; Rahim et al., 2014; Ryan, 2016; Zeinali et al., 2014)

Battour, M., \& Ismail, M. N. (2016). Halal tourism: Concepts, practises, challenges and future. Tourism Management Perspectives, 19, 150-154. https://doi.org/10.1016/j.tmp.2015.12.008

Battour, M., Ismail, M. N., \& Battor, M. (2011). The impact of destination attributes on Muslim tourist's choice. International Journal of Tourism Research, 13(6), 527 540. https://doi.org/10.1002/jtr.824

Hamid, A. B. A., Wahab, M. H. A., Alias, A., \& Rahmat, N. (2016). Significance of Prayer Room Design Standards at Shopping Complex. Proceedings of the 2nd 
International Colloquium of Art and Design Education Research (i-CADER 2015), May, 521-532. https://doi.org/10.1007/978-981-10-0237-3_51

Misiani Mwencha, P., \& Makau Muathe, S. (2018). Customers' Perceptions as an Antecedent of Satisfaction with Online Retailing Services. Journal of Marketing and Consumer Behaviour in Emerging Markets, 1/2018(7), 4-27. https://doi.org/10.7172/2449-6634.jmcbem.2018.1.1

Rahim, A. A., Amirah, N., \& Samad, A. (2014). Universal Design from Islamic Perspective: Malaysian Masjid. Journal of Architecture, Planning and Construction Management, 4(2).

Ryan, C. (2016). Halal tourism. Tourism Management Perspectives, 19(April), 121-123. https://doi.org/10.1016/j.tmp.2015.12.014

Zeinali, B., Jafarpour, M., Hessam, A., Shojaeivand, B., \& Zolghadr, H. (2014). Tourists' Satisfaction with and Loyalty to Shopping Experience: A Socio-Demograhic Analysis. International Journal of Academic Research in Business and Social Sciences, 4(6), 67-84. https://doi.org/10.6007/ijarbss/v4-i6/927

UKEssays. (November 2018). Marketing Islamic Travel Destinations A Religious Perspective Tourism Essay. Retrieved from https://www.ukessays.com/essays/tourism/marketing-islamic-travel-destinationsa-religious-perspective-tourism-essay.php?vref $=1$

Received: $15^{\text {th }}$ May 2020. Accepted: $1^{\text {st }}$ Sept 2020 